\title{
The tragedy that should never have happened
}

W ho would want to be joined at the head with another person knowing separation is impossible and life an agony? I doubt a physician in Canada would be willing to accept this cruel fate.

So why were all the specialists involved in the recent Tatiana and Krista Hogan-Simms conjoined twin birth in British Columbia smiling while they were interviewed on television? Why didn't at least one have the courage to say, "This birth should never have happened?" Or, "This birth is a cruel experiment and will cost taxpayers millions of dollars in medical and social costs - money that could be used for other pressing needs." But there was just smiles, and talk about the surgical challenges ahead.

It's frightening for this country that no one involved in this media event mentioned its negative and tragic aspect. Instead, the media were tripping over themselves, describing the twins as "Little Darlings."

For me, this entire media event was disturbing and I expressed this view and my opinion that the pregnancy should have been terminated in my newspaper column, "The Doctor Game," published by 6o Canadian newspapers.

Reaction was swift. Most readers agreed with me. Some were furious at the millions needed for the twin's care and their constant drain on our health care system. Others thanked me for being brutally honest and having the courage to write about this inhumane cruelty. And some worried that editors might fire me.

I also received damning responses from those who consider life to be precious at any price. I was labelled a "wicked physician," and told "Thank God you're not my doctor." One critic believed I had "gone "crackers." Some Christian readers insisted that "God does not make mistakes." But other religious people thought that even God had made an error in this instance, and would have chosen abortion.

We are a compassionate nation, but

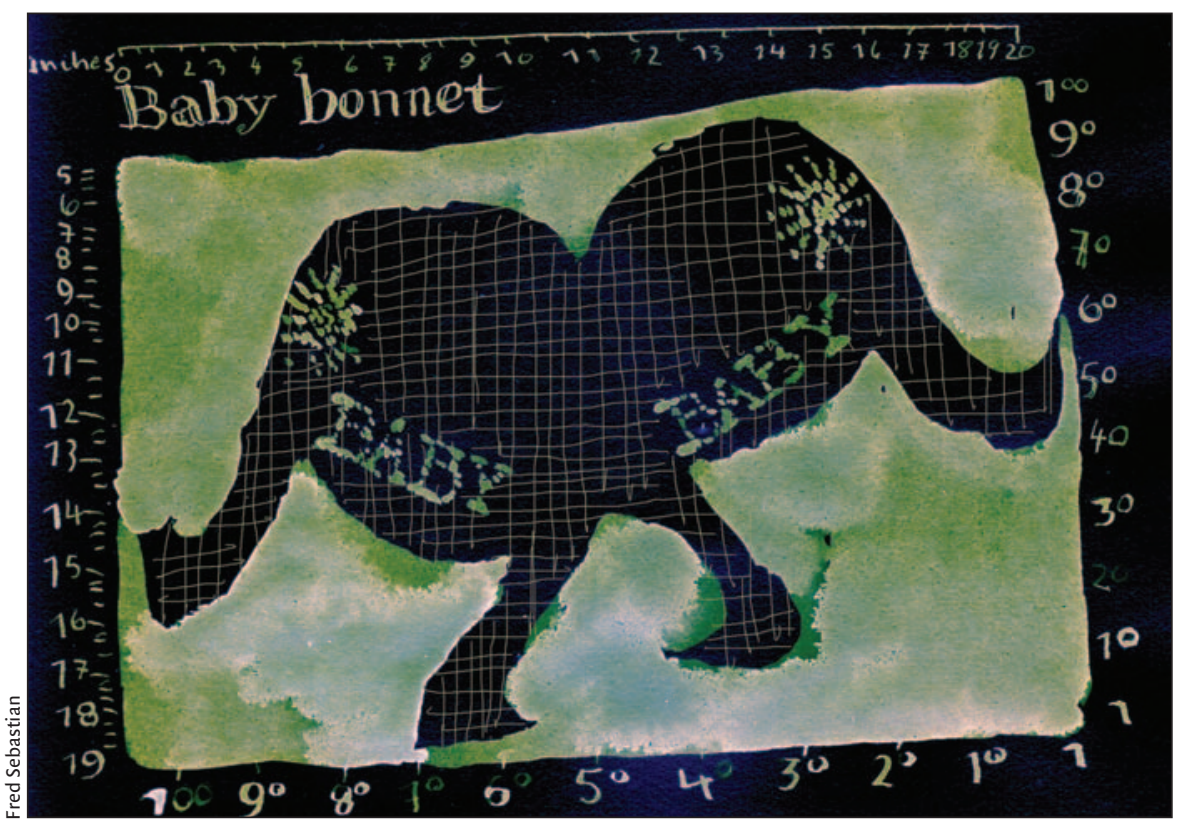

in this case too compassionate; our health care system cannot afford reckless expenditures of this kind. There is already a seemingly infinite need for medical care, but the means are finite. Like it or not, we have reached a point where some medical decisions have to be based on financial realities.

Many will argue that no one should be denied medical care. But we have been withholding care for years: patients suffer for months, sometimes years, waiting for a hip replacement, and thousands of Canadians lack a family physician. But we have millions of taxpayer's dollars to spend for years of treatment on a cruel abnormality of nature.

Felicia Hogan-Simms was given the choice of terminating her pregnancy. But she believes her twins were born to teach people to be tolerant and that it's okay to be "different."

Seventeen years ago the State of Oregon introduced legislation stating that medical treatment that was not cost effective would not be on the approved list.

The message must also be delivered to Canadians that we cannot live for health care alone. Economists have predicted that annual increases in health costs will eventually mean there's no money for anything else!

Talleyrand once remarked to Napoleon, "Sire, worse than a crime you have committed an error." In this case a monumental error was committed by allowing this pregnancy to continue. And it should be a wakeup call for all those involved in funding our health care system.

Unfortunately, no one had the intestinal fortitude to deliver this message. But I have one suggestion for those who believe the conjoined twins can lead a happy life. Bind your head together with someone else for one week. Then, and only then, can the debate be free of ethical, moral and religious issues. Cruel reality will overwhelm.

\section{Ken Walker MD}

Dr. Walker writes "The Doctor Game," published weekly in 60 Canadian papers.

Have you got an opinion about this article? Post your views at cmaj.ca. Potential Salon contributors are urged to read our online guidelines and send inquiries to salon@cma.ca. 